\title{
メソフェースピッチ系炭素繊維の構造
}

\author{
稻垣道夫 ${ }^{* 1}$, 遠藤守信 ${ }^{* 2}$, A. Oberlin ${ }^{* 3}$, 木村脩 七 $^{* 4}$ \\ 中溝 実 $^{* 5}$, 菱山幸宥 ${ }^{* 6}$, 藤巻洋人 ${ }^{* 7}$
}

（昭和 54 年 8 月 2 日受理）

\section{Structure of a Mesophase Pitch-based Carbon Fiber}

\author{
M. Inagaki, ${ }^{* 1}$ M. Endo, ${ }^{* 2}$ A. Oberlin, ${ }^{* 3}$ S. Kimura, ${ }^{* 4}$ M. Nakamizo, ${ }^{* 5}$ \\ Y. Hishiyama ${ }^{* 6}$ and H. Fujimaki*7 \\ *1 Toyohashi University of Technology, Tempaku-cho, Toyohashi, 440 \\ *2 Faculty of Engineering, Shinshu University, Wakasato, Nagano, 380 \\ *3 Laboratoire Marcel Mathieu, 45045 Orleans-la Source, France \\ *4 Tokyo Institute of Technology, Nagatsuda-cho, Yokohama, 227 \\ *5 National Industrial Research Institute of Kyushu, Tosu, Saga, 841 \\ *6 Musashi Institute of Technology, Tamazutsumi, Setagaya, Tokyo, 158 \\ ${ }^{* 7}$ Nishiki Laboratory, Kureha Chem. Ind. Co., Nishiki-cho, Iwaki, 974
}

The structure of one of mesophase pitch-based carbon fibers with random cross sectional texture was studied by various techniques; X-ray diffraction, magnetoresistance, laser Raman spectroscopy, high resolution electron microscopy, electron diffraction from periphery of the fiber, polarized light microscopy and scanning electron microscopy.

The fibers used were prepared from the mesophase pitch by spinning at $370{ }^{\circ} \mathrm{C}$, oxidizing at $325^{\circ} \mathrm{C}$ and then heating up to $900^{\circ} \mathrm{C}$ (Ref. 2). Their diameter was about $20 \mu \mathrm{m}$ and the density was $1.74 \mathrm{~g} / \mathrm{cm}^{3}$. The fibers were heat-treated at $3000^{\circ} \mathrm{C}$ for $30 \mathrm{~min}$ in the flow of argon. They were also heat-treated at different temperatures, $1600^{\circ}, 2000^{\circ}, 2500^{\circ} \mathrm{C}$, for about $10 \mathrm{sec}$ in order to know the process of structural change.

The results of X-ray diffraction, magnetoresistance and laser Raman spectroscopy were summarized in Table 1. The interlayer spacing $\bar{d}_{002}$ decreased with the increase in heat treatment temperature, but the growth of apparent thickness of crystallite $L_{c}$ was restrained. The positive value of maximum transverse magnetoresistance $(\Delta \% / 0)_{\max }$ and small value of intensity ratio $R$ of $1360 \mathrm{~cm}^{-1}$ line to $1580 \mathrm{~cm}^{-1}$ line indicated relatively high degree of graphitization of the fiber heat-treated at $3000^{\circ} \mathrm{C}$. The value of anisotropy factor $A$ close to 1 and small values of half-maximum width of the orientation function $\varphi_{1 / 2}$ which were determined both from X-ray diffraction and magnetoresistance measurement revealed the remarkable orientation of crystallites along the fiber axis. On the $3000^{\circ} \mathrm{C}$-treated fiber, crystallite orientation in the cross section was observed (Fig. $1 \mathrm{c}$, $\mathrm{T}$ arrangement) and it seemed to be related to the deformation of the cross section of the fiber (Fig. 6). The relations between $\bar{d}_{002}$ and $L_{c}$, and also between $(\Delta \% / 0)_{\max }$ and $R$ did not coincide with those found on various cokes, that might be due to some constraint from the fibrous shape.

\footnotetext{
*1 豊橋技術科学大学: $\bar{T} 440$ 豊橋市天伯町雲雀ケ丘

*2 信州大学工学部: 7380 長野市若里

*3 Laboratoire Marcel Mathieu: 45045 Orlèans-la-Source, France

*4 東京工業大学工材研：干 227 横浜市緑区長津田町 4259

*5 九州工業技術試験所: $=841$ 鳥栖市宿町

*6 武蔵工業大学物理 : 7158 東京都世田谷区玉堤

*7 点羽化学工業 (株) 錦研究所 : 7974 いわき市錦町落合 16
} 
Under electron microscope, well-developed graphite lamellae with wrinkles were found, their microtexture being clarified by dark-field image technique and electron diffraction (Fig. 2). In the fibers heat-treated at low temperatures, the porous regions with small and randomly-oriented layers coexisted with the regions with well-developed layers (Figs. 3 and 4), the former being hard-carbonlike and the latter soft-carbon-like in the microtexture and its change with heat treatment.

The different values of $R$ were obtained for the single fiber and for its powdered sample (Table 1 ). It means a heterogeneity in the graphitization degree. On the $2500{ }^{\circ} \mathrm{C}$-treated fiber, the value of single fiber was 0.18 and it increased to 0.30 , close to the value for the powdered, after the oxidation in air at $500{ }^{\circ} \mathrm{C}$ for about $5 \mathrm{~h}(15 \%$ weight loss). These experimental results suggest that the periphery of the fiber has higher degree of graphitization than the interior. From polarized light microscopy, the units for optical anisotropy (mosaic units) were found to be smaller in the periphery than in the interior.

\section{1.はじめに}

炭素繊維の優れた性質は広い用途と多くの可能性を生 み出した。そして, そのととが逆に, 炭素繊維の性能の 改良・向上をうながした。そのような性能向上は製造法 の改良によってなされるとともに，原料前駆体の選択・ 改質によってなされてきた。ほとんどの炭素瀻維は前駆 体繊維にいわゆる不融化処理と呼ばれる酸化処理をする 必要があるため, 高い黒鉛化性と結晶子の高い配向度を 望むととは難しく，乙れらを改良する一つの方法として 高温延伸 hot-stretching 操作が導入された。一方，大 谷ら ${ }^{1)}$ はテトラベンゾフェナジンから作った液晶状ピッ チを原料として選択することにより，通常の製造法によ ってより高い黒鉛化性とより高い配向度を持つ炭素繊維 を作りうるととを示した。その後, 加熱処理して異方性 のメソフェースを生成させた石油系ピッチ(液晶含有ピ ッチまたはメソフェースピッチ)からの炭素繊維の製造 法が開発され，それが高い黒鉛化性と高い配向度を持つ ことが報告された ${ }^{2)}$ 。 Singer らのグループも同種の炭 素繊維を開発し，それが高い電導度と高い弾性率を持つ こと, さらに多様な微細組織を賦与しうるととを示し $た^{3,4)}$ 。

我々は, 炭素之言う複雑な構造と性能を持つ材料につ いては，いくつかの研究手段を併用し，それらからの情 報を互いに矛循なく説明しうるモデルを追求する基礎的 な努力が必要であり，それが炭素材料のより正しい理解 に結びつくあのであるととを指摘し，専門之研究手段を 異にする何人かの研究者間での協同研究をいくつか行な ってきた ${ }^{5 \sim 7)}$ 。

本研究では上記のように近年開発された新しい炭素繊 維, メソフェースピッチ系炭素瀻維mesophase pitchbased carbon fiber, の一つを選び，その高温処理試 料を各研究者に配分し，それぞれの研究手段での検討を 行ない，その結果をまとめたあのである。本研究を通し
て, この炭素繊維の構造のより正しい理解に近づくこと が目的であるとともに, 各研究手段の間の相関性や適用 限界についての知見をうるてと屯期待している。研究手 段之担当者は, X線回折 (藤巻, 稲垣), 磁気抵抗(菱山), レザーラマン分光 (中溝), 高分解能電子顕微鏡 (遠藤, Oberlin), 表面層での電子線回折 (菱山), 偏光顕微鏡(木 村), 走査型電子顕微鏡(稲垣)である。また, 試料は呉 羽化学工業(株)より提供をうけ, それを加熱処理 (木村, 藤巻)した。なお，本試料の提供をうけた時期 (1975 年 4 月)より現在までの間に，メソフェースピッチ系炭素 繊維の研究開発がさらに進められ，すでに一部が発表さ れているように ${ }^{2,4)}$, 多様な微細組織が賦与しうるとと が明らかにされている。こてで用いた試料は，そのうち の一種類の微細組織の典型的なものと考えてよい。

\section{2. 実験および実験結果}

\section{1 試 料}

使用した炭素繊維はメソフェースを含むピッチから $370^{\circ} \mathrm{C}$ で押し出し熔融紡系し, 不融化処理後 $900^{\circ} \mathrm{C}$ で炭

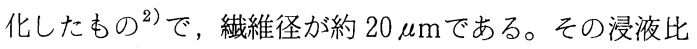
重は $1.73 \sim 1.74 \mathrm{~g} / \mathrm{cm}^{3}$ であった。との繊維をアルゴン気 流中で $3000{ }^{\circ} \mathrm{C}$ に 30 分間加熱処理した。また, 加熱処理 にともなう構造変化の過程を知るために, アルゴン気流 中 1600,2000 および $2500^{\circ} \mathrm{C}$ の各温度にそれぞれ約 10 秒間加熱処理した。

\section{$2.2 X$ 線回折}

各試料瀻維をメノウ乳鉢中で粉砕し, シリコンを内部 標準として, 002 および 004 回折線から平均面間隔 $\bar{d}_{002}$ および結晶子の厚み $L_{c}$ を常法によって算出した。また， 繊維の束について繊維試料台を用いて, 繊維軸に対して 平行 $\left(\varphi=0^{\circ}\right)$ 加垂直 $\left(\varphi=90^{\circ}\right)$ になっている結晶子の濃 度分布曲線(配向関数) を測定し, その配向関数の半価幅 $\varphi_{1 / 2}^{\mathrm{X}}\left(\varphi=0^{\circ}\right.$ での結晶子濃度の半分の濃度を持つ角度, 上の添字は $X$ 線回折による測定值を意味する)をむって 
Table 1 Characteristics of a mesophase pitch-based carbon fiber.

\begin{tabular}{|c|cccc|ccc|cc|}
\hline$H T T$ & \multicolumn{4}{|c|}{ X-ray Diffraction } & \multicolumn{3}{|c|}{ Magnetoresistance } & \multicolumn{3}{|c|}{ Laser Raman } \\
$\left({ }^{\circ} \mathrm{C}\right)$ & $\bar{d}_{002}$ & $L_{c}(002)$ & $L_{c}(004)$ & $\varphi_{1 / 2}^{\mathrm{x}}$ & $(\Delta \rho / 0)_{\max }$ & $A$ & $\varphi_{1 / 2}^{\mathrm{m}}$ & $R_{\text {single }}$ & $R_{\text {powder }}$ \\
\hline 900 & - & - & - & 24.6 & - & - & - & 0.93 & - \\
1600 & 3.47 & 35 & - & 17.2 & - & - & - & 0.87 & 0.89 \\
2000 & 3.433 & 97 & 54 & 12.4 & -0.102 & 0.949 & 17.3 & 0.56 & 0.84 \\
2500 & 3.398 & 183 & 90 & 8.0 & -0.246 & 0.974 & 11.8 & 0.18 & 0.37 \\
3000 & 3.378 & 180 & 90 & - & 1.07 & 0.992 & 6.1 & 0.15 & - \\
\hline
\end{tabular}

結晶子配向の度合を表わす尺度とした。これらの結果を

Table 1 中に示した。

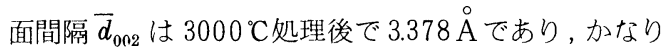
黒鉛化が進んでいると言える。結晶子の厚み $L_{c}(002)$ は 180 Åと必ずし屯大きくはない。また， $L_{c}(004)$ が $L_{c}(002)$ の約 $1 / 2$ の值であり, 格子歪の存在を示してい る。 $L_{c}$ 值の変化がほとんどなく, $\bar{d}_{002}$ のみが減少して いるととから $2500^{\circ} \mathrm{C}$ 以上では結晶成長よりはむしろ内 部構造の整備，たとえば，欠陥の除去が起とっていると 言えよう。繊維軸に関する結晶子の配向度はかなり著し いもので，それが加熱処理温度の上昇とともにさらに進 んで, $\varphi_{1 / 2}^{\mathrm{x}}$ が減少している。

\section{3 磁気抵抗}

単繊維を用いて磁気抵抗 $\Delta \rho / \rho$ を測定した。測定は液 体窒素温度で，10 kGまでの磁場で行なった。繊維軸に
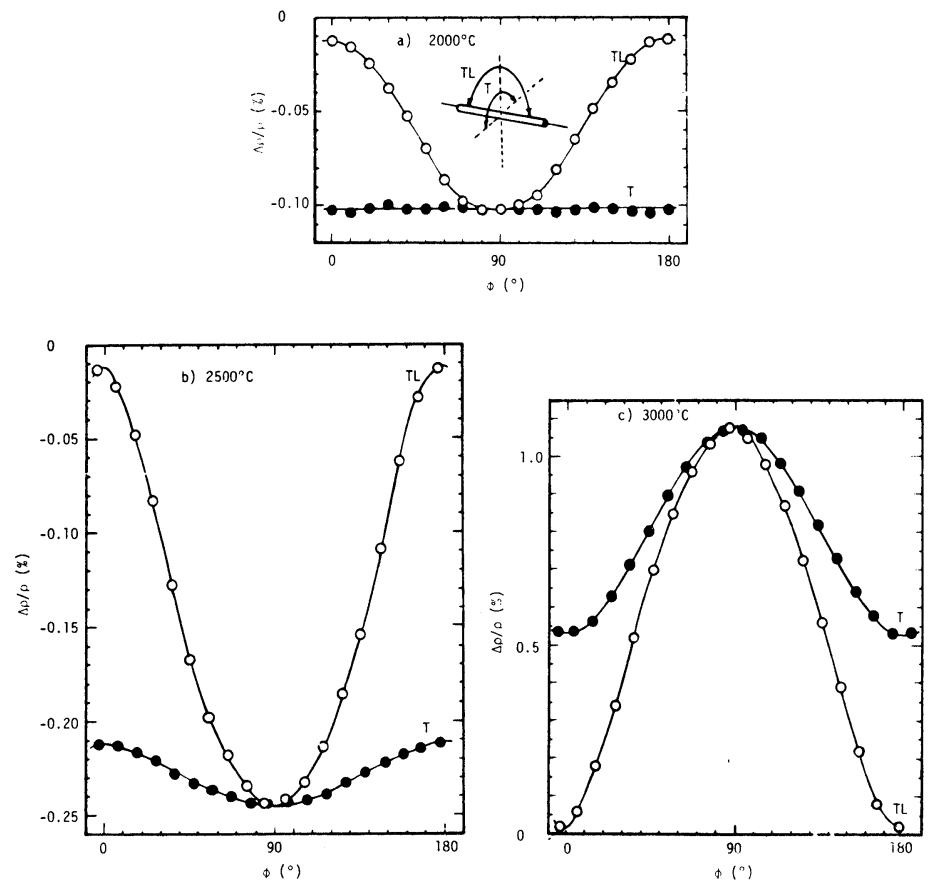

Fig. 1 Angular dependences of magnetoresistance $\Delta \rho / \rho$ for the mesophase pitch-based carbon fibers heat-treated at different temperatures.
対する磁場の方向の関数としての $\Delta \rho / 0$ の測定から, 黑 鉛化度の尺度となりうる最大横磁気抵抗 $(\Delta \rho / O)_{\max }$, 結 晶子の配向の度合を表加す異方性因子 $A$ ，および配向関 係の半価幅 $\varphi_{1 / 2}^{\mathrm{m}}$ (mは磁気抵抗倸よる測定值を意味する) を求め ${ }^{5)}$, Table 1 中に示した。Fig. 1 には2000, 2500 および $3000^{\circ} \mathrm{C}$ 处理の 3 試料についての $\Delta / / 0$ の角度依存 性を示した。TおよびTL配㯰は同図中の插入困に示し た配置での測定結果である。すなわち，T配置において は繊維軸に垂直な面内で磁場を回転させており，その面 内での繊維軸之平行になった黒鉛層面の配向を示し， TL配置は $(\Delta \rho / \rho)_{\text {max }}$ が測定にかかる磁場方向之繊維軸 とが張る平面内で磁場を回転させるもので，繊維軸に平 行な方向から垂直な方向への黒鉛層面の配向を示すすの である。TL配置で測定された $\Delta \rho / \rho の$ 值からX線回折 によって得られる配向関数をその表式中に含む異方性因 子 $A$ が求まる。求めた $A$ の值之, 配向 関数が $\sin ^{n} \varphi$ に比例するとして得た表 式とを組み合わせるととにより $\varphi_{1 / 2}^{\mathrm{m}}$ 決定した。な打, 繊維の場合, $A$ の値 は $0.667 \leq A \leq 1$ であり，1に近いほど 配向度が高い。

$(\Delta \circ / 0)_{\max }$ は $2500^{\circ} \mathrm{C}$ までは負の值 であり， $3000{ }^{\circ} \mathrm{C}$ で正の值となる。これ は炭素材料一般における黒鉛化の進行 による $(\Delta \rho / \rho)_{\text {max }}$ 值の变化上同一傾向 を示しており，ての䄉維においても黒 鉛化が進んでいる。特に 2500 3000 ${ }^{\circ} \mathrm{C}$ の間で急激に進行するととを示して いる。繊維軸に関する結晶子の配向は 非常に良好で，特に $3000^{\circ} \mathrm{C}$ 処理試料 では強い異方性，すなわち $A \doteqdot 1$ で示 されるように高い配向度を示す。繊維 軸回りでの結晶子の配向は $2000^{\circ} \mathrm{C}$ 以 下では，Fig.1のT配置の測定結果が 示すように，ほぼ均一であるのに対し て, 処理温度の上昇によって異方性が 出てくる。 $3000{ }^{\circ} \mathrm{C}$ でのその異方性は かなり大きいと言える。 


\section{4 レザーラマンスペクトル}

レザーラマンスペクトルを単繊維および粉末について 室温で測定した。各試料は黒鉊層面における面内振動に 由来する $1580 \mathrm{~cm}^{-1}$ にあるピークと, 末黒鉛化部分に由 来すると考えられる $1360 \mathrm{~cm}^{-1}$ のピークとから成り，処 理温度の上昇とともに前者に比べて後者が小さくなり， 黒鉛化の進行を示している。その結果を二つのピークの強 度比 $R(=I(1360) / I(1580))$ としてTable 1 中に示した。 $2000{ }^{\circ} \mathrm{C}$ 以上では，単繊維についての測定值と粉末に
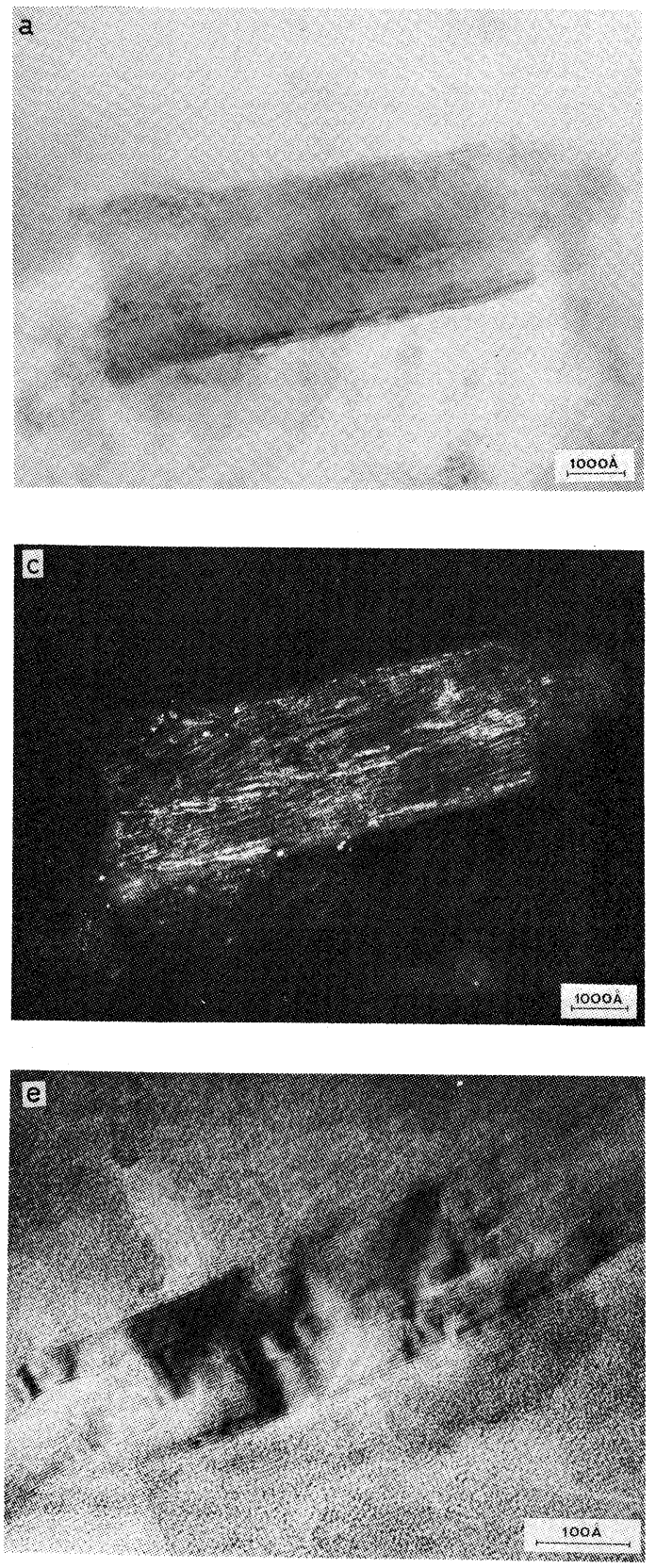

ついてのそれとが異なっており, 前者の方が常に小さい 值を示し, 試料の構造に不均一性のあることを示してい る。 $R$ 值が小さいほど $1360 \mathrm{~cm}^{-1}$ のピークが小さく, 高 い黒鉛化度に対応すること,さらに，レザービームが試料 の極く表面(深さ〜 $250 \AA$ ○内) の情報しか与えないこと を考えると, 䋐維の表面層の方が内部より黒鉛化が進ん でいると推定される。 $2500{ }^{\circ} \mathrm{C}$ 処理試料の単繊維の $R$ 值 は 0.18 であるが, これを $500{ }^{\circ} \mathrm{C}$ で約 5 時間空気中で酸化 したのち(重量減少 $15 \%$, 表面のみが酸化されていると
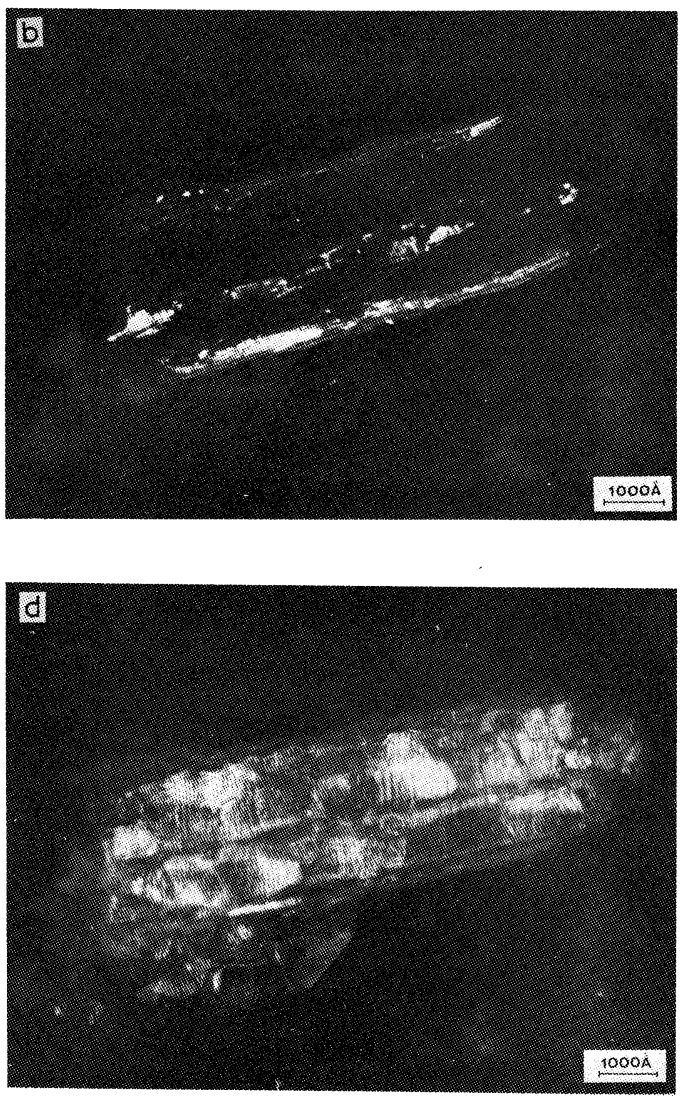

Fig. 2 High resolution electron micrographs of the $3000^{\circ} \mathrm{C}$-treated fiber.
a) bright field image,
b) 00.2 dark field image,
c) 10.0 dark field image,
d) 11.0 dark field image,
e) 00.2 lattice fringes. 
仮定すると約 $4000 \AA ̊ 丿$ の厚さの表面層が取り去られたて ととなる)には， $R$ 值は 0.30 に上昇し，粉末についての 測定做 0.37 に近づいた。との実駼結果は表面層の方が黒 鉛化が進んでいるとの推定を裏付けるものである。3000 ${ }^{\circ} \mathrm{C}$ 处理単繊維の $R$ 值は 0.15 であり，黒鉛化が進んでいる と言える。

\section{5 高分解能電子顕微鏡観察}

あらかじめ繊維試料を粉砕したのち銅メッシュ上にの 女，充分薄い破片を選んで，高分解能電子顕微鏡技術に よって,その微細構造を観察した。

$3000{ }^{\circ} \mathrm{C}$ 処理試料についての明視野像 (a)，002 暗視 野像 (b)，100 暗視野像 (c)，110 暗視野像 (d)，および 002 格子像 (e)をFig. 2 に示した。 $3000^{\circ} \mathrm{C}$ 処理試料で は全ての破片が薄片状をなしており，Fig. 2 に示したも のが代表的なむのと言って差し支えない。100暗視野像 と 110 暗視野像は各々回折リング上で互いに $90^{\circ}$ をなす 方向に絞りを置いた場合の暗視野像であり，各々のモア レ縞の方向が互いにほぼ直角をなしていることから，こ の薄片がよく平行に積層した黒鉛層面から成っていると 考えられる ${ }^{8)}$ 。そして，それにしうがよって抢り，その しわに当る部分では層面が薄片全体としての面に対して 垂直となって (edge-onして)，002 暗視野で輝く(Fig. 2 b)。黑鉛層面が広い範囲にわたって平坦であり，平行 に皘層しているてとが，ての edge-onした部分の格子像 （Fig. 2 e ）から推定される。 2500 C 処理試料であ，Fig. 2 に示したもの之類似の上く配向した薄片部分が数多く 認められるが，その他に層面がランダムに集まった部分 あ認められた。Fig. 3 にその一例を明視野像として示し

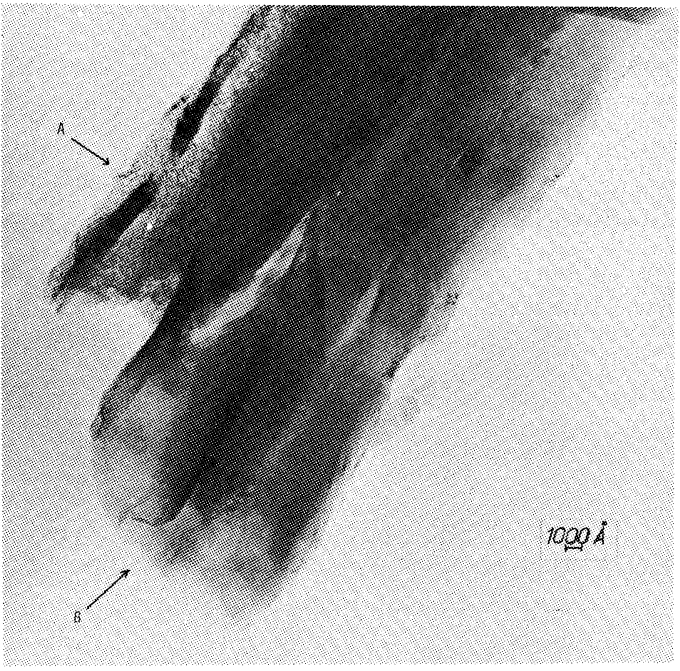

Fig. 3 Bright field image of the $2500{ }^{\circ} \mathrm{C}$-treated fiber.
(A) porous region (B) lamellar region

た。この組織の違いは各種の暗視野像観察でも顕著に認 められた。これらの観察から，配向の良い部分が易黒鉛 化性炭素の組織 ${ }^{9)}$ に似ているのに対して, ランダムな配 向を示す部分は難黒鉛化性炭素の組織に類似していると 言える。

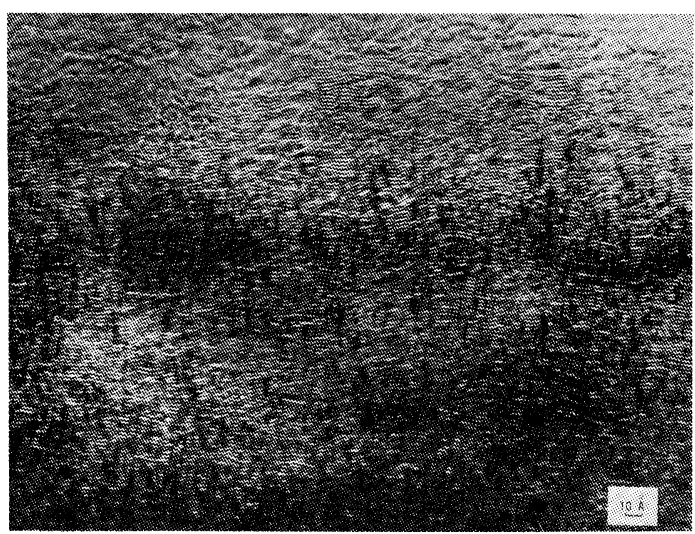

Fig. $4 \quad 00.2$ lattice fringes of the $900{ }^{\circ} \mathrm{C}$-treated fiber.

$900^{\circ} \mathrm{C}$ 処理試料では層面が小さく, Fig. 4 に 002 格子 像として示したように，10３0 月の大きさで2〜3枚が ほぼ平行になって，いわゆる基本ドメイン (elemental domain $\left.{ }^{9)}\right)$ を形成し，それらが或る方向にほほ配向して いる部分が認められる。これが $2500^{\circ} \mathrm{C}$ あるいは $3000^{\circ} \mathrm{C}$ 処理試料で認められた層面が長く平坦で，しかむ平行に 配向した部分の前駆段階に対応すると考えられる。この ような処理温度にともなう組織変化は典型的な易黒鉛化 性炭素であるアンスラセンコークス ${ }^{9,10)}$ ，あるいは気相成 長炭素繊維 ${ }^{11)}$ について認められたあのと同じであると言 える。

\section{6 繊維表面層での電子線回折}

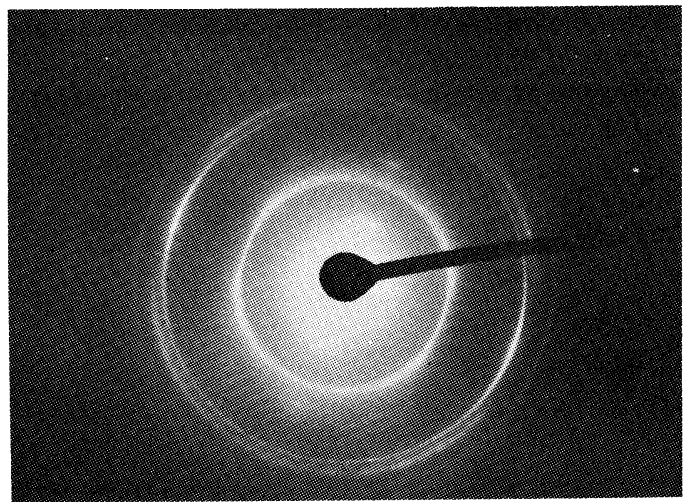

Fig. 5 Electron diffraction pattern from the periphery of the $3000^{\circ} \mathrm{C}$-treated fiber. 
銅メッシュ上の学綫維の表自層加らの制限視野電子線 回折像を観察した。 $3000{ }^{\circ} \mathrm{C}$ 処理試料について観察され た回折像をFig.5に示した。回折条件との関係から厳密 な議論は難しいが，黑鉛層面の三次元樍層走す三次元 回折線 101，112などが認められ，黒鉛化が進んでいる ことが知られる。また，002回折リングは非常に拡がり の狭いアーク状となっており, 層面の配向が非常によい ととが知られる。各武料についての観測から, 002 回折 線アークの拡がりが姏理温度の上昇上とむに減少する傾 向が喼められた。

\section{7 偏光顕微鏡観察}

繊維を樹脂中に包埋し, その断面老研磨し, 偏光下で 観察した。 $2500{ }^{\circ} \mathrm{C}$ 以下で扣熱処理した試料の断面はは ぼ真円に近いのに対して，3000 C 処理試料では，Fig. 6 にその一例圭示したように, 多くの繊維の断面は変形し， 楕円形上なっていた。しかも, 断面全域にわたって黄色 となっている。すなわち, 黒鉛層面が石膏検板の $x^{\prime}$ 万向 にはば平行よなっている。このような断面の变形は繊維

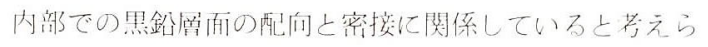

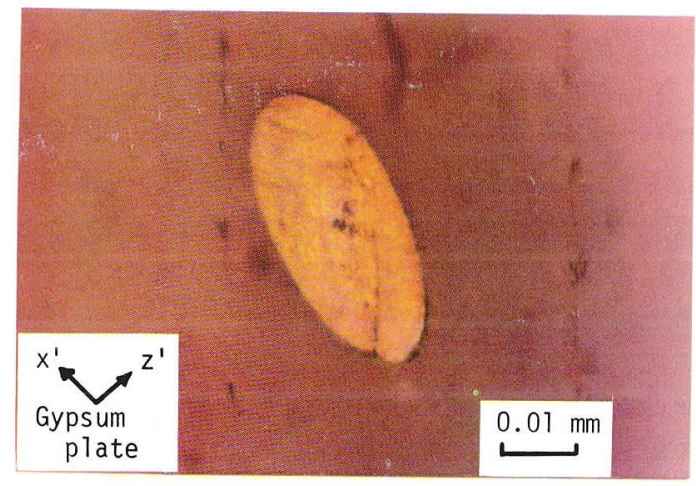

Fig. 6 Polarized light micrograph of the cross section of the $3000^{\circ} \mathrm{C}$-treated fiber.
れる。 $2500^{\circ} \mathrm{C}$ 以下の処理武料について, 異方州在示す 部分は，傾向として繊維断面の中心部に多く，乙れらの 観察からは，繊維中心部の方が周辺部(表面層)上りも異 方性構造の発達が良好である。言い換えれば，照鉙絬晶 子の成原が著しいと言える。この観察絬果は同棰の武料 についての以前の結果 ${ }^{2)}$ と一致している。

\section{8 走查型電子顕微鏡観察}

各試料在走榃型宅子顕微鏡下で観祭した。絬果の一部 をFig. 7 に示した。絨維住はFig.7 a にみられるように， かなり均一であり，また冬単繊維の長さ力问の琒の变動 屯小さい。繊維表百はFig. 7 b 执よび c にタられるよう に，低温処理試料では平坦であったものが，吕温処詶試 料では緎維軸に沿ったすじが認められるようになり，ま た破断面も高温処理試料で凹凹がはげしくなる。

\section{3. 考察}

ここで武料としたメソフェースピッチ系岑䒺絨維は高 い黑鉛化性孝持つことが一つの特徽としてあげられてい

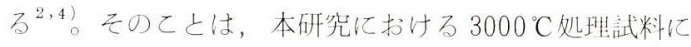
つての各測定值からも結論づけられる。畨百间隔 $\bar{d}_{002}$ が比較的低い值にまで成少している。そして， $\bar{d}_{002}$ およ び $L_{c}(002) の$ 佔はBright and Singer ${ }^{4)}$ が randomな 組織圭持つ繊維について報告している值と一致してい る。最大横磁気抵抗 $(\Delta O / O)_{\text {max }}$ の值は+ $1.07 \%$ 上なり, この值はニードルコークス等の易黒鉛化性炭䒺の高処理 物が示す值に比べればはるかに小さいが，い扣る有機 繊維の炭化・黒鉛化処理によって作られる炭素繊維類 (たよえばPAN系など)が $3000^{\circ} \mathrm{C}$ 処理後も負の值在示

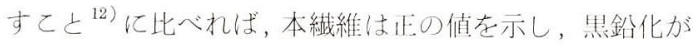
進んでいると言える。ラマン虽度比 $R$ は 0.15 上低い值で あり，黒鉛化が進んでいるとと走し，ニードルコーク 又等の高埧処理物に匹敵する值である。市敗炭素䋊維に ついての值 ${ }^{13)}$ に比べ机かなり小さい值であって，磁文
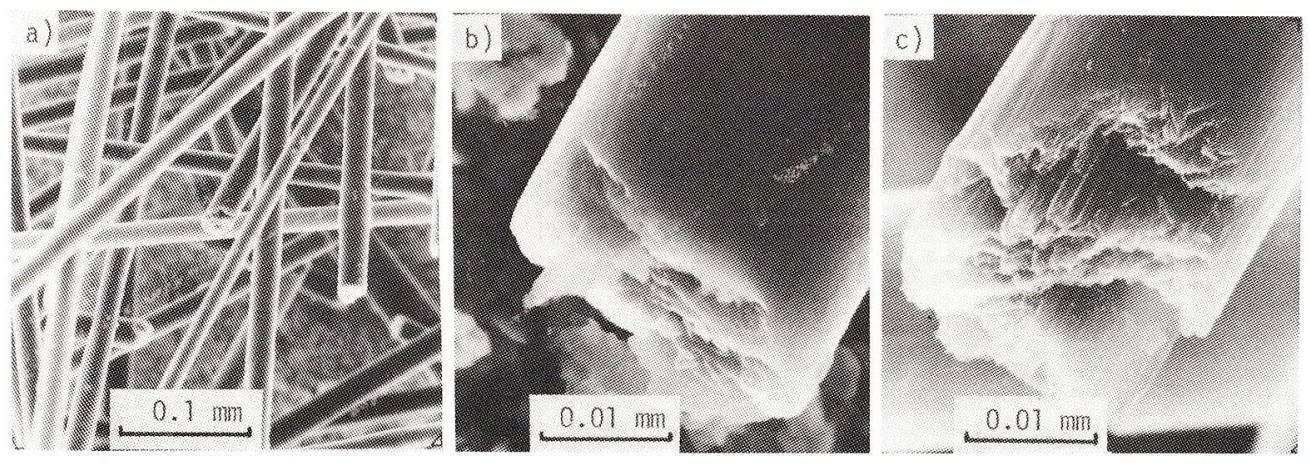

Fig. 7 Scanning electron micrographs of the fibers.

a) $2500{ }^{\circ} \mathrm{C}$-treated, b) $900^{\circ} \mathrm{C}$-treated, and c) $2500{ }^{\circ} \mathrm{C}$-treated. 
抵抗からの結論と一致している。高分解能電子顕微鏡観 祭からも $3000^{\circ} \mathrm{C}$ 処理試料が，非常によく整った大きな 薄片状の黑鉛結昆から成っていることが知られた。暗視 野像でのモアレ縞が均一な周期を示す範囲から推定され

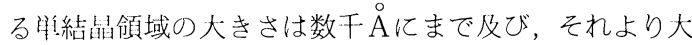
きな絬晶薄片がしうが寄った形をとっていると推定され る。表侕層での電子線回折四形でも, 三次元回折線が明 瞭に認められ，黑鉛化性が良好であるてとを示している。 このように，いずれの測定手段からも，いわゆる有機繊 維加ら作られる炭素繊維よりも高い黒鉛化度を持つこと が結論され，延伸処理を全くほよ゙こすととなく，乙のよ うに啇い黑鉛化度が得られるととが，乙のメソフェース ピッチ系炭素繊維の特徴と言えよう。

泊延伸処理をほどこしたPAN系の繊維について約

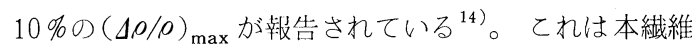
より高い值であり，黒鉛化度において優れている。しか し, Bright and Singer ${ }^{4)}$ は同系の繊維について黒鉛化 性が繊維断洏の微細組織によって大きく左右されるととを 報告し，本繊維と同様の組織を持つと思われる random 組織のものについて，ほぼ本研究と间程度の值を得てい るのに対して, radial 組織と呼ばれるものは $20 \%$ を越 える值 $(14 \mathrm{kG}, 4.2 \mathrm{~K})$ を報告しており，さらに高い黒鉛 化度も期街できる。しかし，ベンゼンの熱分解によって 作った気相成長炭素繊維ほどの高い黑鉛化度 $\left((\Delta O / O)_{\max }\right.$ で $60 \%$ 以上 $\left.{ }^{15)}\right)$ 之完全性の高い黒鉛層面 ${ }^{11)}$ を実現する ことは困難と予想される。

加熱処理によもなう黒鉛化の進行は2500〜3000 $\mathrm{C}$ で 急激に起こることをX線回折および磁気抵抗の測定結果 が示している。 $2500{ }^{\circ} \mathrm{C}$ 以下では黒鉛層面が配向した易 黒鈆化性炭素と類似した部分と，小さな層面が無秩序に 集まり，殼を作って気孔の多い難黑鉛化性炭素と類似し た部分とから成っているととが，高分解能電子顕微鏡観 察から知られた。とのような二種の成分の其存は, 本研 究に打ける原試料である $900^{\circ} \mathrm{C}$ 処理試料ですでに認めら れ，製造過程で生じているものと推定ざれる。

コークス類の黒鉛化過程において，( $(\Delta 0 / 0)_{\max } \subset R$ と の間には或る一定の相関関係があることが示されてい る ${ }^{7)}$ 。し力し，乙とで用いた試料に扔いては，その相関 性とは一致せず， $R$ 值に比べて $(\Delta \rho / \rho)_{\max }$ の值が非常に 小さい。乙の原因は現段階では明らかでないが，コーク ス類の場合は層面が二次元的な拡がりを持ちうるのに対 して, 繊維の場合には繊維軸に沿った方向へは層面が充 分伸びうるが，それと直角な方向には成長が制限される か，少なくとあ $10 \mu \mathrm{m}$ 以下の曲率で曲がっていなければ ならないととに起因しているものと考えられる。試料が 繊維:状の形を保つことの構造変化への制限が $\bar{d}_{002}$ と $L_{c}$
との関係であ認められる。多くのコークス類についての $\bar{d}_{002}$ と $L_{c}$ との相関関係 ${ }^{16)}$ に比較したとき, 本試料につ いての $\bar{d}_{002}$ 值から予想される $L_{c}$ に比べると観測值は大 略半分であり，本試料では結晶成長が制限をうけている か，大きな歪を含んでいるかであると思われる。

この繊維のもう一つの特徵は高い配向度である。この こともX線回折，磁気抵抗の測定結果加ら結論しうる。 特に, 磁気抵抗から求めた異方性因子 $A$ がほとんど 1 に 近く, 繊維軸方向とそれに垂直な方向の磁気抵抗の異方 性は非常に強いことがわかる。また, 配向関数の半価幅 $\varphi_{1 / 2}$ は高温延伸処理繊維とほぼ同じ值である。加熱処 理温度の上昇とともに $\varphi_{1 / 2}$ は減少し, 配向が温度とと あに改良されることが分かる。磁気抵抗から求めた半価 幅 $\varphi_{1 / 2}^{\mathrm{m}}$ とX 線回折から求めた $\varphi_{1 / 2}^{\mathrm{X}}$ とはその值が必ずし あ一致しておらず, $\varphi_{1 / 2}^{\mathrm{m}}$ の方が $\varphi_{1 / 2}^{\mathrm{X}}$ より大きい值を与 えている。熱分解黒鉛についても同様の傾向が認められ ており ${ }^{17)}$ ，配向関数の表示ともど屯，各測定の精度，測 定している物性の異いを考慮に入れて今後検討しなけれ ばならない問題である。

$3000^{\circ} \mathrm{C}$ 処理試料については, Fig. 1 c に示したように, 繊維断面内での異方性が認められた。このととはFig. 6 の断面の形状と関連があると考えられる。低温でははば 均一であった断面内の結晶子の配列が，加熱処理温度の 上昇とともに層面が成長し，しかも或る一方向に配向す る傾向が現われてきたため, 断面が楕円形に変形したと 言えよう。延伸処理したPAN 系炭素繊維についても, 繊維断面内での結晶子配向と断面の変形が，磁気抵抗の 測定之走䍒型電子顕微鏡観察加ら認められている ${ }^{14)}$ 。ま た, 断面の変形のない気相成長炭素繊維では $3000^{\circ} \mathrm{C}$ 処 理物でさえも T配置での $(\Delta \rho / \rho)$ 角度依存がほとんど 認められない(15)。

レザーラマンスペクトルによる $R$ 值は単繊維と粉末試 料之では異なった值を与え，構造に不均一性のあること を示している。そして，それは繊維の表面層が内部より も高い黑鉛化度を持つことに起因することが明らかとな った。市販炭素繊維についての同様の測定も構造の不均 一を示している ${ }^{13)}$ 。また, PAN 系炭素緎維についての 電子顕微鏡観察加, 約 1000 $1500 \AA$ のの厚さの表面層 肪生成しており，それが内部答りも高い黒鉛化度を持つ ことか指摘されている ${ }^{18)}$ 。ただ, 結晶子の配向に関して は表面層が内部より低い配向度を持っている。

偏光顕微鏡観察加らあ断面の組織に不均一があるとと が知られる。本繊維の顕微鏡組織を藤巻ら ${ }^{2)}$ はモザイク 状組織上呼んで扔り， Singer ら ${ }^{4)}$ の randomに対応す る組織である。偏光下で異方性を示すユニットがランダ ムに集合し，それがモザイク状に見えることにそれぞれ 
の呼び名が由来していると思われる。異方性を示すモザ イクの各ユニットの大きさが, 中心部は表面層より大き く, 組織の不均一性が観察される。この観察結果は, 上 記のレザーラマンスペクトルや電子顕微鏡の結果とは矛 循するように見える。しかし，偏光顕微鏡で観察される あのは結晶子の集合体であって，レザーラマンや電子顕 微鏡で検出される原子的構造よりははるかに大きいスケ 一ルであることを考慮すれば，乙れらの二つの結論は別 々に論じられるべきものであることがわかる。Bennett and Johnson ${ }^{18)}$ の中心部で表面層よりも結晶子の配向 が良いと言う結果と偏光顕微鏡の結果が対応するすので あろう。

\section{4. おわりに}

メソフェースピッチ系炭素繊維の一種について, いく つかの研究手段を併用し, その構造について検討した。 その結果，それが高い黒鉛化性と高い配向度，そして中 心部と表面層での微細構造の違いなどを明らかにした。 Bright and Singerの研究 ${ }^{4)}$ が主として電子物性を中 心として行なわれているのに対して, 本研究ではその微 細構造に重点がおかれている。今後, この系の繊維につ いて, Bright and Singerも指摘している，断面での 組織の違いによる黒鉛化度や配向度の違いなどを詳細に 検討してゆく必要があろう。また，てれら特性值の相互 関係を通して, 繊維状であるととのてれら特性値および微 細構造への制約について検討するととも重要と思われる。

\section{引用文献}

1) S. Otani, S. Watanabe, H. Ogino, K. Iijima and T. Koitabashi, Bull. Chem. Soc. Japan 45, 3710 (1972)

2) 藤巻, 小玉, 坂口, 奥田, 大谷, 炭素, 1975 〔No.
80] 3; 藤巻, 大谷, セラミックス, 11, 612(1976)

3) J. B. Barr, S. Chwastiak, R. Didchenko, I. C. Lewis, R. T. Lewis and L. S. Singer, Appl. Polymer Symp. 29, 161 (1976); S. Chwastiak, J. B. Barr and R. Didchenko, Carbon 17, 49 (1979)

4) A. A. Bright and L. S. Singer, Carbon 17, 59 (1979); L. S. Singer, Carbon 16, 409 (1978)

5) Y. Hishiyama, M. Inagaki, S. Kimura and S. Yamada, Carbon 12, 249 (1974)

6) たとえば, Y. Hishiyama, Y. Kaburagi, M. Inagaki, T. Imamura and $\mathrm{H}$. Honda, Carbon 13, 540 (1975); M. Inagaki, A. Oberlin and T. Noda, 炭素 1975 [No. 81] 68; M. Inagaki, J.-C. Rouillon, G. Füg and P. Delhaes, Carbon 15, 181 (1977)

7) M. Nakamizo, H. Honda, M. Inagaki and Y. Hishiyama, Carbon 15, 295 (1977)

8) A. Oberlin, Carbon 17, 7 (1979)

9) A. Oberlin, G. Terriere and J. L. Boulmier, 炭素 1975 [No. 80] 29; 1975 [No. 84] 16

10) A. Oberlin and G. Terriere, J. Microscopie 14, 1 (1972)

11) A. Oberlin, M. Endo and T. Koyama, Carbon 14, 133 (1976); M. Endo, A. Oberlin and T. Koyama, Jap. J. appl. Phys. 16, 1519 (1977)

12) D. Robson, F. Y. I. Assabghy and D. J. E. Ingram, J. Phys. D: Appl. Phys. 4, 1426 (1971)

13) F. Tuinstra, et al. J. Composite Mat. 4, 492 (1970)

14) 菱山, 山田, 炭素, 1974 [No. 77] 55

15) 遠藤守信, 学位論文, 昭和 53 , 名古屋大学, p. 93

16) 稲垣, 炭素, $\mathbf{1 9 6 8}$ [No.53]57; 稲垣, 村瀬, 野 田, 炭素, 1968 [No. 54] 80

17）菱山幸有，学振資料，117-118-C-3，（昭和 47）

18) S. C. Bennett and D. J. Johnson, Carbon 17, 25 (1979) 